\title{
STRATEGI PENGEMBANGAN PRODUK BANK SYARIAH DI INDONESIA
}

\author{
Ahmad Mukhlisin; Aan Suhendri \\ Institut Agama Islam Ma'arif NU Metro Lampung \\ e-mail: ahmadlisin1988@gmail.com; aansuhendri76@gmail.com
}

\begin{abstract}
At present Islamic banking is growing rapidly, along with these developments various types of Islamic Bank products are also growing, where product innovation is the key to Islamic banking to be more competitive and more rapidly developed in accordance with the needs of the community. Product development strategies are one aspect of a marketing strategy. Banking product development is an effort to increase customers by introducing new banking products. The strategy of developing banking products is an effort to increase the number of customers by developing or introducing new banking products. Innovation and creativity in product creation are one of the main keys in this strategy. In general, every Islamic bank in running its business has five operational principles, namely as follows: Principles of pure savings, the principle of profit sharing, the principle of buying and selling, the principle of rent, and the principle of service (fee). Product development strategies are part of a corporate strategy. Islamic banks provide many options for the community to obtain financing that does not only depend on one type of bank with its products, if Islamic banks are able to read the potential of the region and the needs of the population is owned by Islamic banking, the development of Islamic banking products is a necessity for Islamic banks those in the region to be able to answer the needs of the community. This condition can occur can not be separated from the support of DPS who must be active and innovative and be with each bank in the area. As well as product marketing strategies must be carried out by conducting strategic alliances with mass media (radio, television and print media) and event organizers in the form of exhibitions (expo), so that these products are widely known and directly felt by the public at large. In certain expos such as people can directly register for sharia credit cards or make financing requests for the purchase of sharia products that are on display. Through this strategy Islamic banks can get a lot of success, both in increasing portfolios and marketing new products.
\end{abstract}

Keywords: Product Development Strategy, Indonesia Shariah Bank

\section{Pendahuluan}

Bank syariah adalah lembaga perbankan yang menggunakan sistem operasinya berdasarkan pada syariah Islam. Bank adalah salah satu lembaga keuangan yang memberikan sebuah produk berupa jasa, sebagai perusahaan yang bergerak dibidang jasa, bank juga mengikuti konsep produk jasa yang diberikan. Dalam berientasi pada produk perbankan yaitu memfokuskan dalam pembuatan produk yang baik dan perbanikannya terus menerus karena konsumen menyukai produk yang memberikan kualitas dan prestasi yang paling baik.

Dalam pengembangan produk adalah melakukan perbaikan dan menghasilkan produk baru yang berbeda dari produk yang telah ada. Pengembangan produk pada dasarnya yaitu 
usaha yang dilakukan untuk memperbaiki produk yang sedang berjalan atau menambah jenis produk yang belum ada. Bank syariah harus mampu meningkatkan dan memberikan inovasi yang baru pada produk perbankan dan layanan sebagai usaha manajemen dalam menghadapi perubahan selera, teknologi dan persaingan yang semakin meningkat sehingga dapat mempertemukan keinginan pasar melalui produk bank syariah yang tidak ketinggalan dari produk bank konvesional.

Inovasi produk yang menjadi kunci perbankan syariah untuk lebih bermanfaat, kompetitif dan lebih berkembang dengan cepat sesuai dengan kebutuhan masyarakat. Inovasi produk harus menjadi strategi prioritas bagi bank-bank syariah, karena inovasi memiliki peran penting dalam merambah dan menguasai pasar yang selalu berubah. Untuk itu, industri perbankan syariah dituntut melakukan pengembangan, kreativitas dan inovasi-inovasi produk baru. Keberhasilan sistem perbankan syariah di masa depan akan banyak tergantung kepada kemampuan bank-bank syariah menyajikan produk-produk yang menarik, kompetitif dan memberikan kemudahan transaksi, sesuai dengan kebutuhan masyarakat dan industri pasar.

Menurut Sondang P. Siagian menyatakan bahwa pengembangan produk yaitu upaya menarik minat para pelamggan untuk membeli dan menggunakan produk yang baru yang dihasilkan oleh perusahaan tersebut. Dalam pengembangan strategi produk perbankan yang menjadi sasaran para pelanggan yaitu ada tiga jenis kegiatan: 1) mengembangankan dan meluncurkan produk baru, 2) mengembangan variasi mutu produk lama, 3) mengembangkan model dan bentuk tambahan pada produk lama tersebut.

Produk jasa akan menghasilkan suatu penilaian tentang kualitas atau mutu hasil yang baru dapat dibuktikan setelah konsumen menggunakan produk tersebut. Produk yang diberikan akan menjadi perhatian dari konsumen dan akan menjadi ciri khas dari perusahan atau lembaga tersebut. Karakteristik pada bank syariah dalam menjalankan usaha dalam bentuk jasa (service) akan terlihat dari konsep syariah yang menjadi pijakan dalam pengembangan produk bank syariah.

Proses pengembangan produk menjadi lebih terspesialiasasi dan dinamik serta perlu berubah ke arah yang lebih baik lagi dan produk yang dihasilkan oleh perusahaan atau lembaga selalu berarah ke arah yang dinamis untuk memuaskan kebutuhan konsumen. Pengembangan produk memerlukan strategi yang tepat bersama dengan aspek pendukungnya, seperti manusia, infrastruktur, budaya dan inovasi yang berkelanjutan. Penelitian ini ingin menjawab pertanyaan apa saja prinsip-prinsip operasional bank syariah? dan bagaimana strategi pengembangan produk bank syariah?

\section{Strategi}

Kata strategi berasal dari bahasa Yunani "strategia" yang diartikan sebagai "the art of the general" atau seni seorang panglima yang biasanya digunakan dalam peperangan. Dalam pengertian umum, strategi yaitu suatu cara untuk mendapatkan kemenangan atau mencapai tujuan. Strategi pada dasarnya merupakan seni dan ilmu yang menggunakan dan mengembangkan kekuatan (ideologi, politik, ekonomi, sosia-budaya) untuk mencapai tujuan yang telah ditetapkan sebelumnya. ${ }^{1}$

\footnotetext{
${ }^{1}$ Fifi Riyanda, "Strategi Pengembangan Produk Deposito IB Desya Mudharabah pada BPRS Suriyah Cabang Semarang" (Thesis--UIN Walisongo, 2015), 9.
} 
Strategi bagi manajemen operasional pada umumnya dan manajemen organisasi bisnis khususnya ialah rencana berskala besar yang berorientasi jangkauan masa depan yang jauh serta ditetapkan sedemikian rupa sehingga memungkinkan organisasi berinteraksi secara efektif dengan lingkungannya dengan baik dan dalam kondisi persaingan yang semuanya diarahkan pada optimalisasi pencapaian tujuan dan berbagai sasaran organisasi yang bersangkutan. $^{2}$

\section{Bank Syariah}

Bank adalah lembaga perantara keuangan atau biasa disebut financial intermediary. Artinya lembaga yang dalam aktivitasnya berkaitan dengan masalah uang. Sedangkan bank syariah yaitu bank yang beroperasi dengan tidak mengandalkan pada bunga, atau dengan kata lain adalah lembaga keuangan yang usaha pokok memberikan pembiayaan dan jasa-jasa lain dan lalu lintas pembayaran serta peredaran uang yang pengoperasiannya disesuaikan dengan prinsip syariat Islam. ${ }^{3}$

Berdasarkan pasal 1 ayat 1 Undang-Undang No. 21 tahun 2008, perbankan syariah adalah segala sesuatu yang menyangkut tentang bank syariah dan unit usaha syariah, mencakup kelembagaan, kegiatan usaha, serta cara dan proses dalam melaksakan kegiatan usahanya. Transaksi dalam pendapatan bank syariah yaitu transaksi muḍarabah dan mushārakah. Bank syariah adalah bank yang menjalankan kegiatan usahanya berdasarkan prinsip syariah dan menurut jenisnya terdiri atas bank umum syariah dan bank pembiayaan rakyat syariah. ${ }^{4}$

\section{Pengembangan Produk}

Pengembangan produk adalah kegiatan yang mengaarah pada ciri khas yang baru atau berbeda dari sebuah produk atau pemanfaatan konsumen. Pengembangan tersebut membentang dari konsep yang sama sekali baru untuk memenuhi keinginan konsumen yang ditetapkan secara baru hingga modifikasi atau memperbaharui dari produk yang sudah ada sebelumnya, ini merupakan sebuah proses yang harus berkesinambungan untuk menahan masa penurunan dalam daur hidup intrinsik dari sebuah produk yang ada. ${ }^{5}$

Dalam arti lain pengembangan produk adalah suatu usaha yang direncanakan dan dilakukan secara sadar untuk memperbaiki produk yang ada, atau untuk menambah banyaknya ragam produk yang dihasilkan oleh perusahaan dan kemudian dipasarkan. Pengembangan produk tersebut terdiri atas suatu penjualan yang bertambah dan diusahakan oleh perusahaan dengan mengembangkan produk-produk yang diperbaharui untuk pasar yang sekarang. ${ }^{6}$

Dapat disimpulkan bahwa pengembangan produk adalah suatu usaha yang dilakukan oleh perusahaan mengembangan produk yang sudah ada atau menghasilkan produk baru serta

\footnotetext{
2 Tiara Dini Arifah, "Strategi Pengembangan Produk Pembiayaan Musyarakah Pada Usaha Mikro Dan Kecil (Studi Kasus: BPRS Khasanah Ummat Kembaran Banyumas)," (Thesis--IAIN, 2017), 7.

3 Anjarini Mandasari, "Pola Pengembangan Produk Bank Syariah Dalam Meningkatkan Kualitas Manajerial (Studi Kasus Di BRI Syariah Cabang Yogyakarta”, (Thesis--UIN Sunan Kalijaga, 2010), 7.

${ }^{4}$ Siti Masulah, "Strategi Pengembangan Perbankan Syariah Di Indonesia," Jurnal Akuntansi Unesa, Vol. 2, No. 2 (2014), 3.

${ }^{5}$ Norman A. Hart dan Jhon staplenton, Kamus Marketing, Cet. ke-2 (Jakarta: PT Bumi Aksara, 2005), 163.

${ }^{6}$ Moekijat, Kamus Manajemen (Bandung: Mandar Maju, 1990), 438.
} 
melakukan pendekatan strategi untuk meraih keberhasilan dan terhindar dari risiko, dan menyajikan produk-produk yang menarik, kompetitif dan memberikan kemudahan dalam transaksi, serta sesuai dengan kebutuhan masyarakat dan industri pasar.

\section{Metode Penelitian}

Jenis penelitian yang digunakan dalam tulisan ini yaitu dengan menggunakan metode studi kepustakaan untuk menggali dasar-dasar teori yang berkaitan dengan pengembangan produk bank syairah. Metode yang digunakan dalam tulisan ini adalah metode kualitatif deskriptif kualitatif karena data yang diperoleh merupakan data kualitatif, yaitu berupa keterangan-keterangan dalam bentuk uraian. Deskriptif karena tulisan ini menganalisa ketentuan-ketentuan dasar mengenai strategi pengembangan produk pada bank syariah.

Dalam metode penelitian ini pula, digunakan cara berfikir deduktif, yaitu suatu cara penganalisaan objek ilmiah tertentu dengan jalan menetapkan suatu ketentuan umum yang kemudian ditarik suatu kesimpulan khusus, karena tujuan tulisan ini menghubung-hubungkan masalah itu dengan teori ilmu-ilmu tertentu, melalui cara berfikir deduktif. Dalam tulisan ini diangkat dari bagaimana strategi dalam pengembangan produk bank syariah, kemudian menarik kesimpulan.

\section{Produk Bank Syariah}

Pengembangan inovasi produk perbankan syariah mengacu pada standar syariah (shariah standards) dan shariah governance, berpedoman pada standar internasional, pemenuhan integritas dan kualitas sumber daya manusia perbankan Islam, kesesuaian akad, dan tidak mendzalimi masyarakat sebagai konsumen. ${ }^{7}$

Pada sistem operasi bank syariah, pemilik dana menanamkan uangnya di bank tidak dengan motif mendapatkan bunga, tetapi dalam rangka mendapatkan keuntungan bagi hasil. Dana nasabah tersebut kemudian disalurkan kepada mereka yang membutuhkan (misalnya modal usaha) dengan perjanjian pembagian keuntungan sesuai kesepakatan.

Pembiayaan dalam perbankan syariah tidak bersifat menjual uang yang mengandalkan pendapatan bunga atas pokok pinjaman yang diinvestasikan, tetapi dari pembagian laba yang diperoleh pengusaha. Pendekatan bank syariah mirip dengan investment banking di mana secara garis besar produk adalah muḍārabah (trust financing) dan mushārakah (partnership financing), sedangkan yang bersifat investasi diimplementasikan dalam bentuk muräbahah (jual-beli).

Pola simpanan yang diajarkan oleh Islam, umat Islam mempunyai pendapatan yang harus diproduktifkan dalam bentuk investasi. Maka bank Islam menawarkan tabungan investasi yang disebut dengan muḍarabah (simpanan bagi hasil atas usaha bank). Untuk membagihasilkan usaha bank kepada penyimpan muḍärabah, bank syariah memberikan jasa perbankan kepada masyarakat dalam bentuk berikut. ${ }^{8}$

\footnotetext{
7 Budi Sukardi, "Kepatuhan Syariah (Shariah Compliance) dan Inovasi Produk Bank Syariah di Indonesia," AKADEMIKA: Jurnal Pemikiran Islam, Vol. 17, No. 2 (2012), 14.

8 Amir Machmud dan Rukmana, Bank Syariah Teori, Kebajikan, dan Studi Empiris di Indoensia (Jakarta: Erlangga, 2010), 28.
} 
Pertama pembiayaan untuk berbagai kegiatan investasi atas dasar bagi hasil terdiri dari: 1) Pembiayaan investasi bagi hasil muḍārabah, yaitu adalah bentuk kerjasama antara dua pihak atau lebih di mana pemilik modal (șạhib al-māt) mempercayakan sejumlah modal kepada pengelola (muḍārib) dengan suatu perjanjian pembagian keuntungan. Bentuk ini menegaskan kerjasama dengan kontribusi seluruh modal dari șạhib al-māl dan keahlian dari muḍārib. ${ }^{9}$ 2) Pembiayaan investasi bagi hasil mushārakah, yaitu akad kerja sama antara dua pihak atau lebih untuk melakukan usaha tertentu. Yang masing-masing pihak memberikan kontribusi dana atau amal dengan kesepakatan bahwa keuntungan atau resiko akan ditanggung bersama sesuai dengan kesepakatan. Disyaratkan bercampur antara harta dari kedua pihak yang bekerja sama sehingga tidak dapat dibedakan harta dari kedua pihak tersebut. ${ }^{10}$

Kedua pembiayaan untuk berbagai kegiatan perdagangan atau jual beli terdiri dari: 1) pembiayaan salam, yaitu transaksi jual beli di mana barang yang diperjual belikan belum ada, barang diserahkan secara tangguh sementara pembayaran dilakukan tunai. Dalam transaksi ini kualitas, kuantitas, harga dan waktu penyerahan barang harus ditentukan. 2) pembiayaan istiṣnā', yaitu transaksi jual beli dalam bentuk pemesanan pembuatan barang berdasarkan persyaratan tertentu, kriteria, dan pola pembayaran sesuai dengan kesepakatan. Seperti untuk pembangunan proyek perumahan, gedung sekolah, listrik, pertambangan dan lain lain. 3) Pembiayaan perdangan al-bay' bi thaman àjil atau dikenal sebagai muräbaḥah, yaitu transaksi jual beli di mana bank menyebutkan jumlah keuntungan. Bank bertindak sebagai penjual, sementara nasabah sebagai pembeli. Harga jual adalah harga beli bank dari pemasok ditambah keuntungan (margin). Dari pembiayaan perdagangan tersebut, bank akan memperoleh pendaptan berupa (mark-up) atau (margin) keuntungan. ${ }^{11}$

Ketiga pembiayaan pengadaan barang untuk disewakan atau untuk disewabelikan dalam bentuk: 1) Sewa guna usaha atau disebut ijärah, 2) Sewa beli atau disebut al-bay' al-takjiri. Ijärah, sewa murni, seperti halnya penyewaan traktor dan alat-alat produk lainnya (operating lease). Dalam teknis perbankan, Bank dapat membeli dahulu equipment yang dibutuhkan oleh nasabah kemudian menyewakan dalam waktu dan hanya yang telah disepakati kepada nasabah. Dan al-bay' al-takjīi atau ijärah al-muntahiya bi al-tamlik merupakan penggabungan sewa dan beli, di mana si penyewa mempunyai hak untuk memiliki barang pada akhir masa sewa (financial lease). ${ }^{12}$

Keempat pemberian pinjaman tunai untuk kebajikan (al-qarḍ al-ḥasan) tanpa dikenakan biaya apapun kecuali biaya administrasi berupa segala biaya yang diperlukan untuk sahnya perjanjian utang, seperti bea materai, bea akta notaris, bea studi kelayakan. Dari pemberian pinjaman al-qard al-ḥasan, bank akan menerima kembali biaya administrasi.

\footnotetext{
9 Trimulato, "Pengembangan Produk Bank Syariah Melalui Investasi Mudharabah dengan Bagi Hasil yang Pasti," Jurnal Akuntansi dan Bisnis, Vol. 15, No. 2 (2015), 78.

${ }^{10}$ Mansur Chadi Mursadi dan Anny Ratnawati, "Potensi dan Strategi Pengembangan Bank Syariah di Indonesia: Kajian Produk Syariah dari Segi Fiqih Muamalat," Jurnal Hukum Islam IAIN Pekalongan, Vol. 9, No. 2 (2011), 3.

${ }^{11}$ Adiwarman A. Karim, Bank Islam Analisis Fiqih dan Keuangan (Jakarta: PT. Raja Grafindo Persada, 2010), 98.

${ }^{12}$ Muhammad, Manajemen Bank Syari'ah (Yogyakarta: UPP-Sekolah Tinggi Ilmu Manajemn YKPN, 2011 ), 90.
} 
Kelima Fasilitas perbankan umumnya yang tidak bertentangan dengan syariah, seperti penitipan dalam dalam rekening lancar (current account), dalam bentuk giro wadi'ah yang diberi bonus dan jasa lainnya untuk memperoleh balas jasa (fee), seperti pemberian jaminan (al-kafālah), pengalihan tagihan (al-ḥiwālah), dan lain-lain. Dari pemakaian fasilitas tersebut bank akan memperoleh berupa fee. ${ }^{13}$

\section{Prinsip-Prinsip Operasional Bank Syariah}

Prinsip-prinsip operasional bank syariah menjadi dasar beroperasinya bank syariah, yaitu dengan tidak mengenal konsep bunga uang dan tidak kalah pentingnya, yaitu untuk tujuan komersial Islam. Secara umum, setiap bank Islam dalam menjalankan usahanya mempunyai lima prinsip operasional.

Pertama, prinsip simpanan murni. Yaitu fasilitas yang diberikan oleh bank untuk memberikan kesempatan kepada kepada pihak yang kelebihan dana untuk menyimpan dananya dalam bentuk al-wadi'ah, yang diberikan untuk tujuan investasi guna mendapatkan keuntungan seperti halnya tabungan atau deposito. Dalam dunia perbankan konvensional alwadi' ah indentik dengan giro.

Kedua, prinsip bagi hasil, adalah sistem yang mengikuti tata cara pembagian hasil usaha antara penyedia dana dan pengelola dana, maupun antara bank dengan bank nasabah penerima dana. ${ }^{14}$ Seperti (mựārabah dan mushārakah) yaitu meliputi tata cara pembagian hasil usaha antara pemilik dana (săhib al-mā̄) dan pengelola dana (mudạarib). Pembagian hasil ini dapat terjadi antara bank dengan penyimpanan dana maupun antara bank dengan nasabah penerima dana.

Ketiga, prinsip jual beli, seperti (murābaḥah, istịnnā' dan salam). Yaitu pembiayaan bank yang diperhitungkan secara lump-sum dalam bentuk nominal di atas kredit yang diterima nasabah penerima kredit dari bank. Biaya bank tersebut ditetapkan sesuai dengan kesepakatan antara bank dengan nasabah.

Keempat, prinsip sewa. Sewa adalah akad pemindahan hak penggunaan atau pemanfaatan atas barang atau jasa dengan melalui pembayaran sewa kepada pemilik. Prinsip ijārah atau sewa terdiri dari dua macam, yaitu ijārah (sewa-menyewa) dan ijärah muntahiya bi al-tamlik (sewa dengan hak opsi atau sewa beli). Ijärah tanpa kepemilikan, yaitu pemindahan hak penggunaan atau pemanfaatan tanpa diikuti dengan pemindahan kepemilikan atas barang itu sendiri. Ijärah muntahiya bi al-tamlik (financial lease with purchase option) yaitu perpaduan antara kontrak jual beli dan sewa-menyewa, atau dengan kata lain akad sewa yang diakhiri pemindahan kepemilikan ke tangan penyewa. ${ }^{15}$

Kelima, prinsip jasa ( $f e e$ ), meliputi seluruh kekayaan non-pembiayaan yang diberikan bank. Bentuk produk yang didasarkan pada prinsip ini antara lain seperti, bank garansi, inkaso, kliring, jasa transfer, dan sebagainya. ${ }^{16}$

\footnotetext{
${ }^{13}$ Amir Machmud dan Rukmana, Bank Syariah Teori, 29.

${ }^{14}$ Siti Masulah, "Strategi Pengembangan Perbankan Syariah di Indonesia," 4.

15 Ahmad Supriyadi, "Sistem Pembiayaan Berdasarkan Prinsip Syariah (Suatu Tinjauan Yuridis Terhadap Praktek Pembiayaan di Perbankan Syariah di Indonesia)," Al-Mawarid, Vol. 10 (2003), 55.

${ }^{16}$ Siti Masulah, "Strategi Pengembangan Perbankan Syariah di Indonesia," 5.
} 


\section{Akad Pelayanan Jasa}

Akad pelengkap dikembangkan sebagai akad pelayanan jasa. Adapun akad-akad tersebut terdiri dari Hawālah, Rahn, Wakālah, Kafălah, Sarf, adapun hal-hal tersebut kami jelaskan di bawah ini.

Hawālah (alih utang-piutang), adalah pengalihan utang dari orang yang berutang kepada orang lain yang wajib menanggungnya. Kontrak ḥawālah dalam perbankan biasanya diterapkan pada factoring (anjak piutang), post-dated check, di mana bank bertindak sebagai juru tagih tanpa membayarkan dulu piutang tersebut. Tujuan fasilitas hawālah adalah untuk membantu supplier mendaptkan modal tunai agar dapat melanjutkan produksinya. Bank mendapat ganti biaya atas jasa pemindahan piutang. Contohnya, supplier bahan bangunan menjual barangnya kepada pemilik proyek yang akan dibayar dua bulan kemudian. Karena kebutuhan supplier akan likuiditas, maka ia meminta bank untuk mengambil alih piutangnya. Bank akan menerima pembayaran dari pemilik proyek.

Rahn (gadai), adalah menahan salah satu harta milik si peminjam sebagai jaminan atas pinjaman yang diterimanya. Barang yang ditahan tersebut memiliki nilai yang ekonomis. Dengan demikian, pihak yang menahan memperoleh jaminan untuk dapat mengambil kembali seluruh atau sebagian piutangnya. Secara sederhana dapat dijelaskan bahwa rahn adalah semacam jaminan utang atau gadai. ${ }^{17}$ Tujuan akad gadai adalah untuk memberikan jaminan pembayaran kembali kepada bank dalam memberikan pembiayaan. Barang yang digadaikan wajib memenuhi kriteria: 1) milik nasabah sendiri, 2) jelas ukuran, sifat, dan nilai ditentukan berdasarkan nilai riil pasar, 3) dapat dikuasai namun tidak boleh dimanfaatkan oleh bank. Atas izin bank, nasabah dapat menggunakan barang tertentu yang digadaikan dengan tidak mengurangi nilai dan merusak barang yang digadaikan. Apabila barang yang digadaikan rusak, maka nasabah harus menutupi kekurangannya.

Wakālah (perwakilan). Wakālah terjadi apabila nasabah memberikan kuasa kepada bank untuk mewakili dirinya melakukan pekerjaan jasa tertentu. Dalam aplikasi perbankan syariah, wakālah biasanya diterapkan dalam penerbitan Letter of Credit (L/C) atau penerusan permintaan akan barang dalam negeri dari bank di luar negeri (L/C ekspor). Wakālah juga diterapkan untuk mentransfer dana nasabah kepada pihak lain seperti inkaso dan transfer. ${ }^{18}$

Kafälah (garansi bank). Garansi bank dapat diberikan dengan tujuan untuk menjamin pembayaran suatu kewajiban pembayaran. Bank dapat mensyaratkan nasabah untuk menempatkan sejumlah dana untuk fasilitas ini sebagai rahn. Bank dapat pula menerima dana tersebut dengan prinsip wadi'ah. Untuk jasa-jasa ini, bank mendapatkan pengganti biaya atas jasa yang diberikan. ${ }^{19}$

Sarf adalah transaksi pertukaran antara uang dengan uang. Pengertian pertukaran uang yang dimaksud yaitu pertukaran valuta asing, di mana mata uang asing dipertukarkan dengan mata uang domestik atau mata uang lainnya. ${ }^{20}$

\footnotetext{
17 Nofinawati, “Akad dan Produk Perbankan Syariah," FITRAH: Jurnal Kajian Ilmu-ilmu Keislaman, Vol. 8, No. 2 (2014), 233.

${ }^{18}$ Siti Masulah, "Strategi Pengembangan Perbankan Syariah di Indonesia," 6.

19 Adiwarman A. Karim, Bank Islam Analisis Fiqih dan Keuangan, 104.

${ }^{20}$ Siti Masulah, "Strategi Pengembangan Perbankan Syariah di Indonesia," 8.
} 


\section{Strategi Pengembangan Produk Bank Syariah}

Strategi pengembangan produk merupakan bagian dari strategi korporasi (corporate strategy). Dalam strategi pengembangan produk terdapat potensi keuntungan maupun risiko dari aktivitas pengembangan produk, dan banyak faktor yang menyebabkan suatu organisasi mempertimbangkan melakukan pengembangan produk baru. Hampir seluruh organisasi menemukan bahwa pendekatan strategi manajerial pada aktivitas pengembangan produk baru akan meningkatkan peluang keberhasilan serta meminimasi biaya dan risiko. ${ }^{21}$

Pada saat ini, pasar perbankan secara umum diidentifikasi mengarah kepada permintaan terhadap layanan pinjaman cepat seperti kredit tanpa agunan dan kredit skala kecil (mikro). Hal yang sama terjadi pada perbankan syariah disebabkan target pasar yang sama dan adanya kecenderungan replikasi produk (product mirroring) perbankan syariah dari perbankan konvensional. Hal semacam ini dapat menyebabkan peningkatan pembiayaan yang bersifat konsumtif. Maka dari itu diperlukan produk penyeimbang yang mendukung sektor produktif. Selain itu, produk yang meningkatkan kebersamaan bank dan nasabah juga perlu dikaji dan dikembangkan, agar core product perbankan syariah yang merupakan sharing economics tetap dapat dipertahankan. Untuk keperluan tersebut, kajian mengenai produk bagi hasil, yaitu mushārakah mutanāqiṣah dan mựārabah muqayyadah harus giat dilaksanakan. Tentu saja upaya pengkajian seperti ini mesti melibatkan semua pihak, termasuk di dalamnya industri dan lembaga pendukung. Momentum ini tepat karena bertepatan dengan upaya dari pemerintah menyediakan perumahan murah bagi masyarakat. ${ }^{22}$

Dewan Pengawas Syariah yang bereran sebagai pengawas, juga berperan sebagai advisor, yaitu pemberi nasehat, inspirasi, pemikiran, saran serta konsultasi untuk pengembangan produk dan jasa yang inovatif untuk persaingan global. Sebagai marketer, yaitu menjadi mitra strategis untuk peningkatan kuantitas dan kualitas industri LKS melalui komunikasi massa untuk memberikan motivasi, penjelasan dan edukasi publik sebagai penyiapan SDM, dan peran strategis lainnya dalam bentuk hubungan kemasyarakatan (public relationship). Sebagai supporter, yaitu pemberi berbagai support dan dukungan baik networking, pemikiran, motivasi, doa dan lainnya untuk pengembangan perbankan dan ekonomi syariah. Sebagai player, yaitu sebagai pemain dan pelaku ekonomi syariah baik sebagai pemilik, pengelola, nasabah penyimpan/investor maupun mitra/nasabah penyaluran dan pembiayaan.

Adanya bank syariah banyak memberikan pilihan bagi masyarakat untuk memperoleh pembiayaan yang tidak hanya bergantung pada satu jenis bank dengan produk-produknya, tetapi masyarakat bebas memilih lembaga dan produk mana yang paling sesuai dengan kapasitas yang dimiliki dan kondisi usaha yang dijalankan. Jika bank syariah mampu membaca potensi wilayah dan kebutuhan penduduk tersebut telah dimiliki perbankan syariah, maka pengembangan produk perbankan syariah menjadi satu keniscayaan bagi bank syariah yang ada di wilayah tersebut agar mampu menjawab kebutuhan masyarakat. Kondisi ini dapat

21 Sutan Remy Sjahdeini, Perbankan Syariah Produk-Produk dan Aspek Hukumnya (Jakarta: Kencana Pranamedia, 2014), 193.

22 Fahrur Ulum, "Inovasi Produk Perbankan Syariah diý Indonesia," Al-Qanun: Jurnal Pemikiran dan Pembaharuan Hukum Islam, Vol. 17, No. 1 (2014), 48. 
terjadi tidak terlepas dari dukungan Dewan Penasehat Syariah (DPS) yang harus aktif dan inovatif serta berada pada masing-masing bank yang ada di daerah. ${ }^{23}$

Strategi pemasaran produk mesti diselenggarakan dengan melakukan aliansi strategis dengan media massa (radio, televisi dan media cetak) dan penyelenggara kegiatan (event organizer) berupa pameran (expo), agar produk tersebut dikenal luas dan langsung dirasakan manfaatnya oleh masyarakat luas. Dalam ekspo tertentu seperti masyarakat dapat langsung mendaftar untuk kartu kredit syariah atau melakukan permohonan pembiayaan untuk pembelian produk syariah yang sedang dipamerkan. Melalui strategi ini bank syariah bisa mendapat banyak keberhasilan, baik dalam peningkatan portofolio maupun pemasaran produk baru. $^{24}$

\section{Kesimpulan}

Secara umum, setiap bank Islam dalam menjalankan usahanya mempunyai lima prinsip operasional, yaitu prinsip simpanan murni, prinsip bagi hasil, prinsip jual beli, prinsip sewa, dan prinsip jasa (fee). Strategi pengembangan produk merupakan bagian dari strategi korporasi (corporate strategy). Bank syariah banyak memberikan pilihan bagi masyarakat untuk memperoleh pembiayaan yang tidak hanya bergantung pada satu jenis bank dengan produk-produknya, jika bank syariah mampu membaca potensi wilayah dan kebutuhan penduduk tersebut telah dimiliki perbankan syariah, maka pengembangan produk perbankan syariah menjadi satu keniscayaan bagi bank syariah yang ada di wilayah tersebut agar mampu menjawab kebutuhan masyarakat. Kondisi ini dapat terjadi tidak terlepas dari dukungan Dewan Penasehat Syariah (DPS) yang harus aktif dan inovatif serta berada pada masingmasing bank yang ada di daerah. Serta strategi pemasaran produk mesti diselenggarakan dengan melakukan aliansi strategis dengan media massa (radio, televisi dan media cetak) dan penyelenggara kegiatan (event organizer) berupa pameran (expo), agar produk tersebut dikenal luas dan langsung dirasakan manfaatnya oleh masyarakat luas. Dalam ekspo tertentu seperti masyarakat dapat langsung mendaftar untuk kartu kredit syariah atau melakukan permohonan pembiayaan untuk pembelian produk syariah yang sedang dipamerkan. Melalui strategi ini bank syariah bisa mendapat banyak keberhasilan, baik dalam peningkatan portofolio maupun pemasaran produk baru.

\section{Daftar Rujukan}

Arifah, Tiara Dini. "Strategi Pengembangan Produk Pembiayaan Musyarakah Pada Usaha Mikro Dan Kecil (Studi Kasus: BPRS Khasanah Ummat Kembaran Banyumas).” Thesis--IAIN, 2017.

Ghofur, Ruslan Abdul. "Konstruksi Akad Dalam Pengembangan Produk Perbankan Syariah di Indonesia." AL- 'ADALAH, Vol. 12, No. 3, 2015.

Karim, Adiwarman A. Bank Islam Analisis Fiqih dan Keuangan. Jakarta: PT. Raja Grafindo Persada, 2010.

Machmud, Amir dan Rukmana. Bank Syariah Teori, Kebajikan, dan Studi Empiris di

\footnotetext{
${ }^{23}$ Ruslan Abdul Ghofur, "Konstruksi Akad dalam Pengembangan Produk Perbankan Syariah di Indonesia," $A L$ 'ADALAH, Vol. XII, No. 3 (2015), 504.

24 Ulum, "Inovasi Produk Perbankan Syariah diý Indonesia," hlm. 49.
} 
Indonesia. Jakarta: Erlangga, 2010.

Mandasari, Anjarini. "Pola Pengembangan Produk Bank Syariah dalam Meningkatkan Kualitas Manajerial (Studi Kasus Di BRI Syariah Cabang Yogyakarta." Thesis--UIN Sunan Kalijaga, 2010.

Masulah, Siti. "Strategi Pengembangan Perbankan Syariah di Indonesia." Jurnal Akuntansi Unesa, Vol. 2, No. 2, 2014.

Moekijat. Kamus Manajemen. Bandung: Mandar Maju, 1990.

Muhammad. Manajemen Bank Syari'ah. Yogyakarta: Sekolah Tinggi Ilmu Manajemn YKPN, 2011.

Mursadi, Mansur Chadi dan Anny Ratnawati. "Potensi dan Strategi Pengembangan Bank Syariah di Indonesia: Kajian Produk Syariah dari Segi Fiqih Muamalat.” Jurnal Hukum Islam IAIN Pekalongan, Vol. 9, No. 2, 2011.

Nofinawati. "Akad dan Produk Perbankan Syariah." FITRAH: Jurnal Kajian Ilmu-ilmu Keislaman, Vol. 8, No. 2, 2014.

Norman, A Hart. dan Jhon Staplenton. Kamus Marketing, Cet. ke-2. Jakarta: PT Bumi Aksara, 2005.

Riyanda, Fifi. "Strategi Pengembangan Produk Deposito IB Desya Mudharabah pada BPRS Suriyah Cabang Semarang." Thesis--UIN Walisongo, 2015.

Sjahdeini, Sutan Remy. Perbankan Syariah Produk-Produk dan Aspek Hukumnya. Jakarta: Kencana Pranamedia, 2014.

Sukardi, Budi. "Kepatuhan Syariah (Shariah Compliance) dan Inovasi Produk Bank Syariah di Indonesia." AKADEMIKA: Jurnal Pemikiran Islam, Vol. 17, No. 2. 2012.

Supriyadi, Ahmad. "Sistem Pembiayaan Berdasarkan Prinsip Syariah (Suatu Tinjauan Yuridis Terhadap Praktek Pembiayaan di Perbankan Syariah di Indonesia)." Al-Mawarid, Vol. 10, 2003.

Trimulato. "Pengembangan Produk Bank Syariah melalui Investasi Mudharabah dengan Bagi Hasil yang Pasti." Jurnal Akuntansi dan Bisnis, Vol. 15, No. 2, 2015.

Ulum, Fahrur. "Inovasi Produk Perbankan Syariah di Indonesia." Al-Qanun: Jurnal Pemikiran dan Pembaharuan Hukum Islam, Vol. 17, No. 1, 2014. 